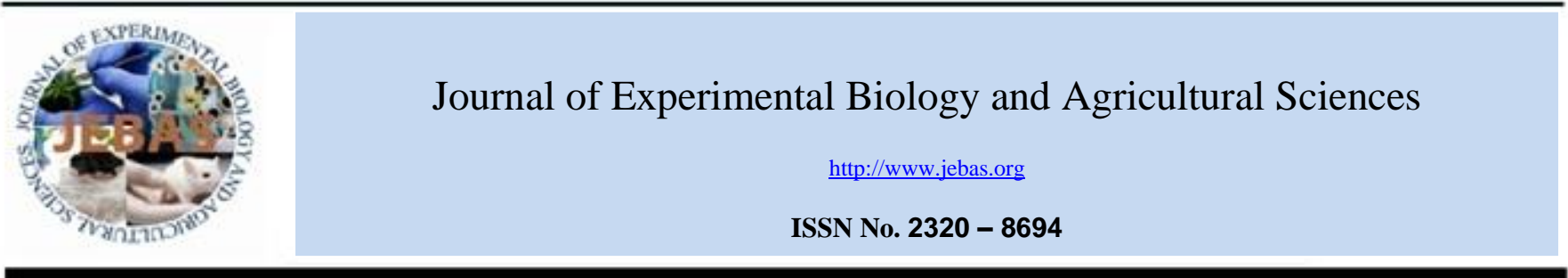

\title{
IMPACT OF COVID-19 PANDEMIC AND LOCKDOWN ON THE MEAT CONSUMPTION PATTERN IN INDIA: A PRELIMINARY ANALYSIS
}

\author{
C. K. Faslu Rahman ${ }^{1 *+}$ (D), Khan Sharun ${ }^{2 * \dagger}$ (D), R. R. $\operatorname{Kumar}^{1}$ (D), Sagar Chand ${ }^{1}$ (D), D. $\operatorname{Bardhan}^{3}$, \\ Kuldeep Dhama ${ }^{4}$ (iD)
}

\begin{abstract}
${ }^{1}$ Division of Livestock Products Technology, ICAR-Indian Veterinary Research Institute, Izatnagar, Bareilly-243 122, Uttar Pradesh, India ${ }^{2}$ Division of Surgery, ICAR-Indian Veterinary Research Institute, Izatnagar, Bareilly-243 122, Uttar Pradesh, India

${ }^{3}$ Division of Livestock Economics, Statistics and Information Technology, ICAR-Indian Veterinary Research Institute, Izatnagar, Bareilly-243 122, Uttar Pradesh, India ${ }^{4}$ Division of Pathology, ICAR-Indian Veterinary Research Institute, Izatnagar, Bareilly, Uttar Pradesh, India.

'Both authors equally contributed to the work and therefore considered the first authors
\end{abstract}

Received - March 18, 2021; Revision - April 03, 2021; Accepted - April 13, 2021

Available Online - April 25, 2021

DOI: http://dx.doi.org/10.18006/2021.9(2).172.182

\section{KEYWORDS}

Meat

Meat consumption

COVID-19

SARS-CoV-2

Lockdown

India

\section{* Corresponding author}

E-mail: ckfaslurahman@gmail.com (Dr. C. K. Faslu Rahman); sharunkhansk@gmail.com (Dr. Khan Sharun)

Peer review under responsibility of Journal of Experimental Biology and Agricultural Sciences.

Production and Hosting by Horizon Publisher India [HPI] (http://www.horizonpublisherindia.in/).

All rights reserved.

\begin{abstract}
The people of India have a wide variety of eating habits that vary according to ethnicity, geography, and culture. The consumption of meat primarily covers the protein requirement of the Indians, and three out of four are non-vegetarians. There is a need to understand the impact of the COVID-19 pandemic and the associated countrywide lockdown on the meat consumption pattern of the Indian non-vegetarians. A countrywide survey was conducted among the consumers to study the impact of COVID-19 on the meat consumption pattern using a self-administered electronic questionnaire distributed through emails and online social networking platforms. A total of 416 responses were collected from the consumers belonging to different states and union territories. The data were analyzed as per the standard procedure. The meat consumption pattern of the non-vegetarians was found to be altered during the COVID-19 pandemic and the lockdown period. The majority of the consumers could not obtain a sufficient quantity of meat and meat products during the lockdown period due to various reasons such as the increased cost and decreased availability of livestock. The myths and rumors associated with meat consumption and the emergence of SARS-CoV-2 further weakened the meat trade in certain areas. Based on the findings of this survey, it is safe to confirm that the meat consumption pattern among Indian consumers was affected badly during the countrywide lockdown.
\end{abstract}

All the articles published by Journal of Experimental Biology and Agricultural Sciences are licensed under a Creative Commons Attribution-NonCommercial 4.0 International License Based on a work at www.jebas.org.

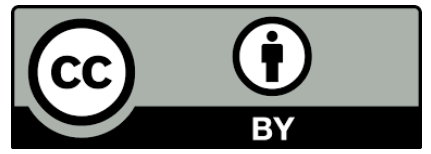




\section{Introduction}

India accounts for a significant share of the global livestock population, with great diversity in the animals and their distribution. Although India is not a major meat-consuming country, it contributes significantly to world meat production. According to the $20^{\text {th }}$ livestock census, India has a livestock population of 535.78 million, with a $4.6 \%$ increase from the previous census (DADF, 2019). The livestock population of India includes a bovine population of 302.79 million (192.49 million cattle and 109.85 million buffalo population). The sheep and goat population was reported to be 74.26 million and 148.88 million, respectively along with a swine population of 9.06 million. The major muscle food resources of India is contributed by poultry, bovines, sheep, goat, pig, and seafood. Also, poultry is the primary meat-producing sector in the country, comprising 851.81 million birds, with a major share accounted for by the commercial poultry industry (comprising 534.74 million birds) (DADF, 2019). The animal husbandry sector of India contributes $30 \%$ of the agricultural GDP, which values over 9 trillion (Bera, 2020).

As per data reported in Basic animal husbandry statistics (2019), published by the Department of Animal Husbandry and Dairying (GOI), the total meat production is 8.11 million tonnes with a $6 \%$ increase than the previous year. Poultry meat contributes half of the total meat produced in the country, with 4.06 million tonnes of production. Buffalo $(19.05 \%)$ and goat $(13.53 \%)$ are the next major meat-producing animals (DADF, 2019). India stands second in bovine meat export with an $18.14 \%$ share globally, behind Brazil (FAS/USDA, 2019). Meat is one of the major sources of nutrients in India, contributing about $35 \%$ of the total protein requirement (Sing, 2020).

According to the Directorate General, Commercial Intelligence, and Statistics (DGCIS, Principal Commodities data April February 2019-20) (APEDA, 2020), India has exported about 10 lakh metric tons of buffalo meat valuing ₹21261 crores (US\$3011 million). In addition to that, India has also exported about 13730 metric tonnes of sheep and goat meat (valuing $\$ 88$ million). The processed meat export was 426 metric tonnes, with a value of US\$2 million. Also, India exports about US\$75 million of poultry products. Animal casing export consists of 11001 metric tonnes with a value of $\$ 49$ million (APEDA, 2020). Buffalo meat contributes about $89 \%$ of the total value of livestock products exported from the country. India accounts for $57 \%$ of the world buffalo population. Indian buffalo meat has worldwide acceptability as it contains $40 \%$ less cholesterol, 55\% fewer calories, $10 \%$ more proteins than beef (Naveena \& Kiran, 2014). India exports both frozen and fresh chilled meat to more than 65 countries around the world. This includes countries such as Vietnam, Egypt, Malaysia, Jordan, Kingdom of Saudi Arabia (KSA), Philippines, Iraq, Myanmar, United Arab Emirates (UAE), and Algeria. Even though India does not directly export to China, a major beef-consuming country, the significant share of beef exported to Vietnam is channelized later to reach China. The major portion of the meat from sheep, goats, pigs, and poultry is primarily used for domestic consumption in the form of hot meat. More than half $(50.06 \%)$ of the meat consumed in India is poultry meat. Consumers vastly prefer chicken over any other meat due to various reasons. In 2019, Indians consumed 4.06 million tonnes of poultry meat $(7.8 \%$ more than the previous year's consumption) (DADF, 2019).

Coronavirus disease 2019 (COVID-19), caused by severe acute respiratory syndrome coronavirus 2 (SARS-CoV-2), has already affected millions of people around the world (Malik et al., 2020; Sharun, 2020). Although SARS-CoV-2 is mainly transmitted by droplets or aerosols, transmission through other routes cannot be ruled out yet (Sharun et al., 2020; Dhama et al., 2021). The recent findings suggest that SARS-CoV-2 might get transmitted through frozen meat (Graham, 2021; Lewis, 2021). It is also hypothesized that infected frozen meat of wild animals bred on farms might have contributed to the outbreak in Wuhan, China (Graham, 2021). Enforcing food safety management systems is a mandate for preventing the outbreak of zoonotic diseases (Halabowski \& Rzymski, 2021). Though the COVID-19 pandemic has created awareness among the people, further measures are to be taken to prevent the possibility of future outbreaks (Faslu et al., 2020a). So, establishing an efficient surveillance system at the human-animal interface can limit the emergence and spread of novel zoonotic diseases such as COVID-19 (Faslu et al., 2020b).

The COVID-19 pandemic has already affected the human lifestyle, including our consumption patterns, especially during the lockdown period (Attwood \& Hajat, 2020; Mayasari et al., 2020). Although several factors have contributed to the changes in our dietary pattern during the COVID-19 lockdown period, the main reason can be attributed to the restriction imposed on the movement of people during the lockdown (Attwood \& Hajat, 2020). The non-vegetarian population of India mainly felt the ultimate repercussions on the consumption patterns. Dramatic changes in the price of meat also affected the demand for such commodities during the lockdown period. This study aims to analyze the impact of COVID-19 and the lockdown on the dietary pattern of Indian meat consumers by performing a countrywide survey using a self-administered electronic questionnaire.

\section{Materials and Methods}

\subsection{Study design}

The cross-sectional study was conducted using a validated, selfadministered electronic questionnaire distributed through emails and online social networking platforms from May 2020 to June 2020. The participants of the study were informed about the objective of the study. 
Table 1 The questionnaire along with the corresponding responses used for collecting data from the meat consumers.

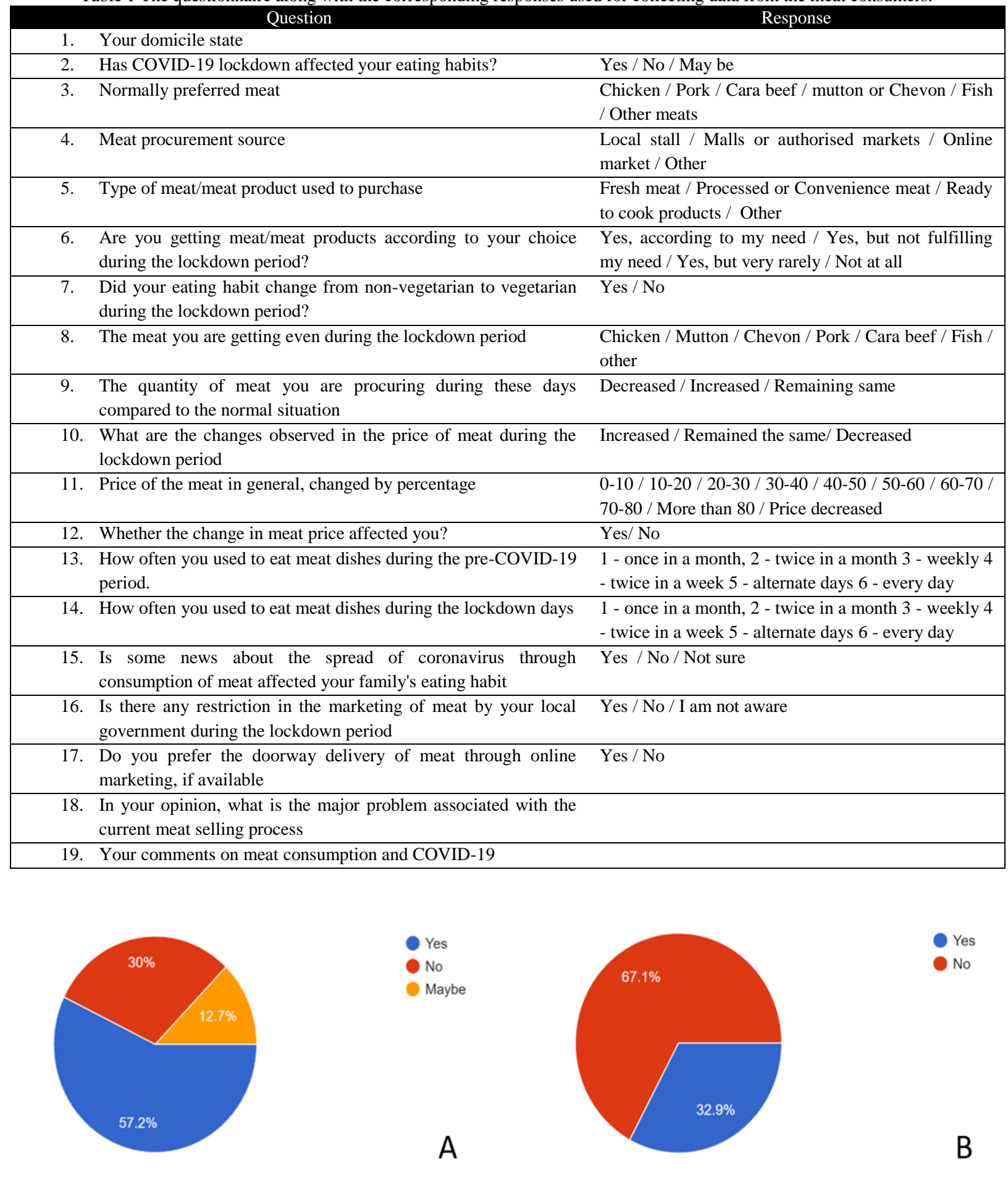

Figure 1 Pie diagram illustrating the response of participants (A) An overall change in the eating habit (B) Diet change from nonvegetarian to vegetarian during the COVID-19 lockdown period. 


\subsection{Questionnaire}

The cross-sectional study was conducted to analyze the impact of COVID-19 on the meat consumption pattern during the lockdown period. The questionnaire consisted of 19 questions and the survey form was prepared using the Google Forms application and was circulated through various electronic means. The study collected data from meat consumers all over the country, represented by all states and union territories. Table 1 presents the questionnaire that was used to collect data from the respondents.

\section{Results and Discussion}

\subsection{COVID-19: Changes in the consumer dietary pattern}

A total of 416 individuals belonging to different states and union territories participated in the study. COVID-19 outbreak in India has altered the consumption pattern of the $70 \%$ of people who participated in the current survey. The primary reason behind the change was the non-availability of products transported from other geographical areas through various transportation methods. The sudden imposition of countrywide lockdown affected all kinds of transport, shutting down the animal markets resulting in the scarcity of meat and meat products due to reduced availability of live animals all over India. However, in certain parts of the country where the meat animal population is high, the locally available stocks were used as meat sources to manage the scarcity.

The major mandies (markets) supplying live animals to the slaughterhouses remained closed during the lockdown period. This had a significant impact on the availability of meat and meat products in different parts of the country. The Deonar mandi (Mumbai) and Ghazipur mandi (Delhi), which earlier supplied goats for south India and north India, respectively, remained closed during this period (Sally, 2020). According to this survey, the lockdown situation prompted $33 \%$ of non-vegetarian respondents to change to a vegetarian diet. This finding was in accordance with the findings of the study performed by Buch (2020), who reported that more than half of the respondents from South Asia avoided non-vegetarian food as a precautionary measure.

\subsection{Impact of COVID-19 pandemic on the meat industry of India}

The Indian meat industry has various components. According to the $20^{\text {th }}$ livestock census, meat production in the country is accounted for by $50 \%$ poultry, $19 \%$ carabeef (buffalo meat), $13.53 \%$ chevon (goat meat), $8 \%$ mutton, $5 \%$ pork, and $4 \%$ beef. In the present study, the majority (64\%) of the respondents cited poultry as their favorite meat, whereas $13.5 \%$ preferred mutton/chevon, about $11 \%$ preferred carabeef, $5.5 \%$ preferred pork, and about $4 \%$ preferred to have fish.
The primary marketing system in the Indian meat sector is mediated through local vendors. The majority of the people prefer the wet/live animal market to any other form as the majority of Indian meat consumers consume fresh meat. Among the participants, $87 \%$ were dependent on the local vendors for meat procurement, while about $6 \%$ preferred to procure the same from malls and supermarkets where fresh and processed meat is appropriately packaged and displayed. Though the online meat markets are at their juvenile stage in India, about $4 \%$ of the respondents in this study procured meat from online sources. Indian online meat market has exhibited growth during the COVID-19 lockdown period in the urban areas, as the other sources, especially malls and authorized meat markets, were mostly shutdown. Licious, an Indian online meat market, witnessed an increase of $200 \%$ in deliveries and a $30 \%$ increase in the average order values from their customers (Gupta, 2020). In the survey, $52.5 \%$ preferred doorway delivery of meat through online marketing, whereas the rest $47.5 \%$ were not interested in procuring meat through online platforms.

According to this survey, the majority of meat consumers preferred fresh meat to processed meat. About $90 \%$ of non-vegetarian consumers preferred fresh meat that was sold through small-scale markets. The preference for processed meats was $7.7 \%$ and, a small percentage of respondents (1.4\%) preferred ready-to-cook products. The demand for meat products and ready-to-cook items were reflected on a much larger scale in the urban areas than in the rural regions.

The availability of meat and meat products in various parts of India varied depending upon the accessibility to stock in that particular region. The survey targeted the status of meat availability in the different geographies. Among meat consumers, about $11 \%$ of consumers could not procure meat or meat products of any kind during the lockdown period. However, about $46 \%$ of respondents stated that they could procure meat and meat products according to their requirements. About $24 \%$ of respondents reported that they could procure meat but not to fulfill their needs. $19.5 \%$ of people responded that they are getting meat very rarely due to scarcity. The variation in the accessibility to meat and meat products in different regions can be attributed to various reasons, including the lack of market, difficulty in transportation, restriction from authorities to sell meat and meat products, and the rumors associated with meat consumption and the emergence of SARSCoV-2.

Among the different meat sources, the chicken was the most available meat during the lockdown period. Eighty-one percent of the respondents reported that they could procure chicken even during the lockdown period. The availability of fish and mutton/chevon were $37.6 \%$ and $24.8 \%$, respectively. However, the availability of carabeef and pork declined drastically to $12.3 \%$ and 


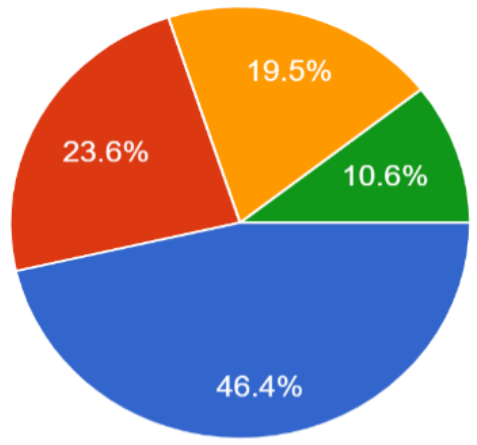

Yes, according to my need

Yes, but not fulfilling my need

Yes, but very rarely

Not at all

Figure 2 Pie chart illustrating the response of participants on the availability of meat and meat products during the lockdown period

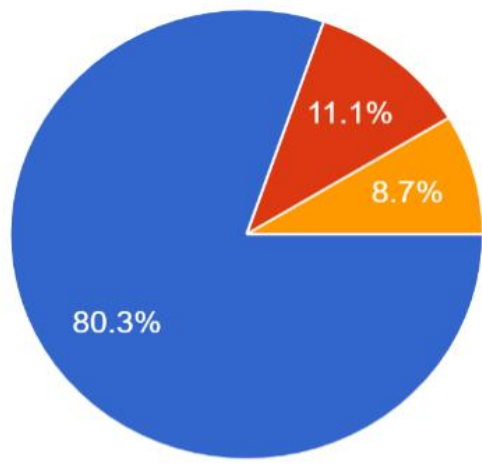

Increased

Remaining same

Decreased

Figure 3 Pie chart illustrating the response of participants on the changes in the price of meat during the lockdown period

$7.7 \%$, respectively. The impact of the COVID-19 lockdown on the transport of livestock might have contributed to this decline. Transportation of larger stocks from outlying areas became impossible, and the available stock of frozen meat in the abattoir declined further when the lockdown was extended, making the situation worse.

In some parts of the country, to avoid gathering, the authorities had imposed a complete ban on the selling of meat and meat products About $39 \%$ of respondents who participated in the survey agreed that there had been a restriction of selling meat in their locality. However, about $44 \%$ of them disagreed with the statement that they did face any restriction from their local government in procuring meat. About $17 \%$ of people were not aware of the restrictions imposed by the local government for the sale of meat and meat products. In the initial period of lockdown (end of March and initial weeks of April), authorities imposed a ban on the sale of meat and meat products due to the spread of rumors. The ban was imposed in Lucknow (Awasthi, 2020), Gujrat (Pachchigar, 2020), Coimbatore (Special correspondent, 2020), Andra Pradesh
(Tippana,2020), Greater Noida (Anand, 2020), and some other parts of India.

\subsection{Impact on the meat price}

Due to the spread of fake news regarding the consumption of meat and the transmission of SARS-CoV-2 at the beginning of the lockdown period, the price of the meat reduced drastically. This price reduction severely affected the Indian poultry industry (The Economic Times, 2020). However, efforts were taken by the government to overcome these rumors. The availability of livestock and poultry was reduced due to reduced transportation of livestock and their feed, causing a sudden surge in the meat price. About $80 \%$ of the respondents reported that there had been an increase in the meat price during the lockdown period. The majority of the participants $(71.1 \%)$ reported a $0-40 \%$ increase in the meat price. However, $22 \%$ of the respondents stated that they faced an increase of $10-20 \%$ in the price of poultry meat. In some parts of India, the price has increased to more than $80 \%$, as reported by about $5 \%$ of the participants. 


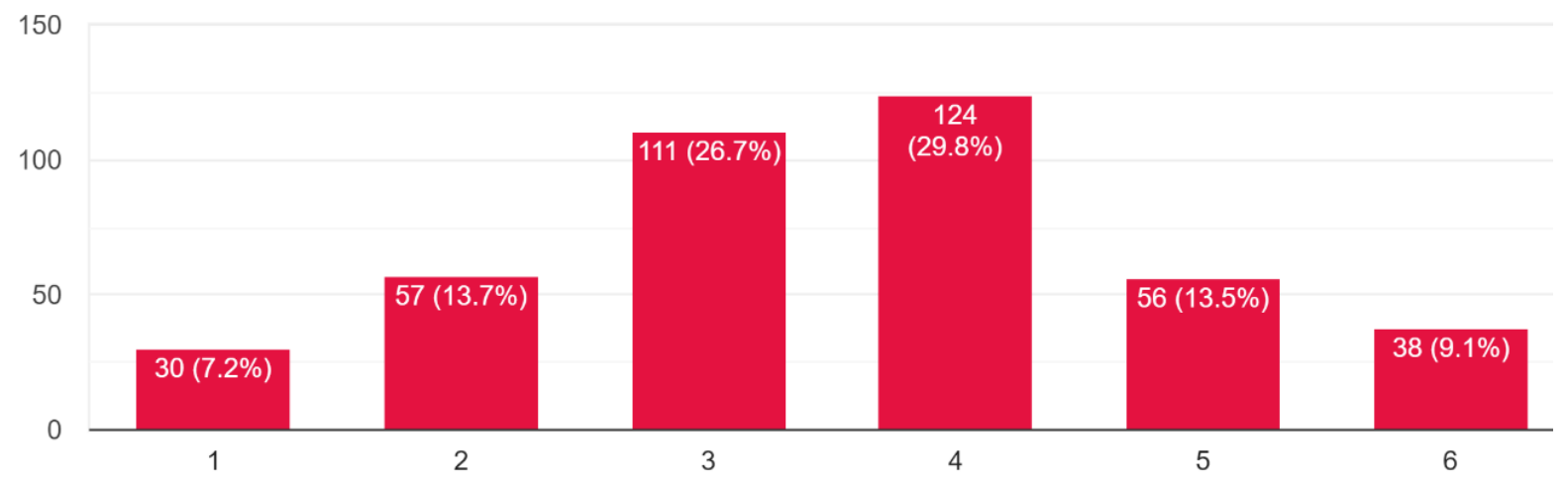

Figure 4 Bar diagram illustrating the response of participants on the frequency of meat consumption during regular days (preCOVID-19 period). Scale: 1 - once in a month, 2 - twice in a month, 3 - weekly, 4 - twice in a week, 5 - alternate days, 6 - daily

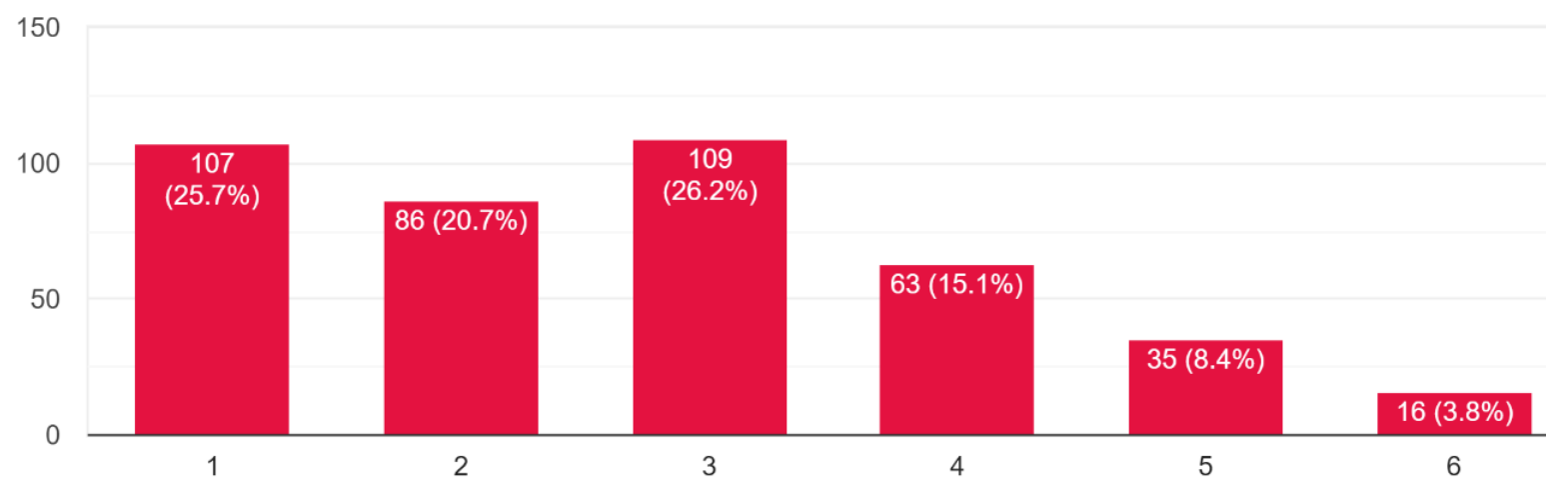

Figure 5 Bar diagram illustrating the response of participants on the frequency of meat consumption during the COVID-19 lockdown period. Scale: 1 - once in a month, 2 - twice in a month, 3 - weekly, 4 - twice in a week, 5 - alternate days, 6 - daily

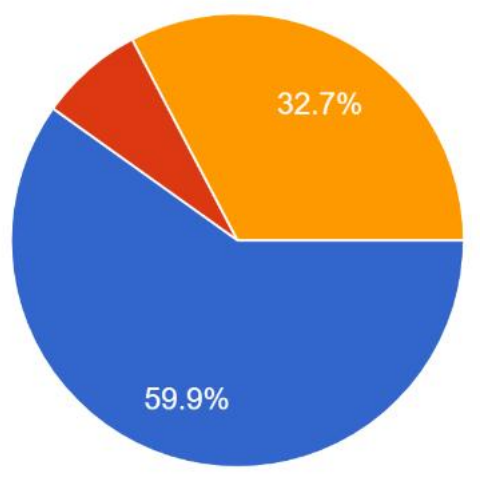

Decreased

Increased

Remaining same

Figure 6 Pie chart illustrating the response of participants on the quantity of meat procured during the lockdown period compared to the normal period

Journal of Experimental Biology and Agricultural Sciences http://www.jebas.org 
The price of chevon and mutton was increased by more than $80 \%$ in major cities as the abattoirs got shut down and the people were unable to bring animals from supply states like Rajasthan. A 50\% surge was reported in the retail price of chevon. The retail price of chevon reached an average price of Rs. $800-900$ per $\mathrm{kg}$ in most of the major Indian cities (Sally, 2020). The price of mutton was increased to Rs.1000/kg in Bengaluru and Madurai due to the scarcity of stock and the increased demand (The Hindu, 2020). In some parts of India, the local government implemented restrictions to regulate the meat prices, and the local governments (mostly at district levels) fixed a standard price for meat consumed in that particular area. In such areas, the price remained the same (as reported by $11 \%$ of the respondents).

In farming areas, due to the restrictions imposed on marketing and transportation, some farmers were forced to sell their livestock at a reduced cost due to the increased maintenance cost and increased feed cost. This scenario contributed to reducing the cost of meat in certain areas. Among the survey participants, $8.7 \%$ of the individuals responded that the meat price had reduced in their locality, whereas $80.3 \%$ reported that the price was increased. Fifty-nine percent of people reacted that the change in meat price affected their meat procurement badly. However, the remaining $41 \%$ reported that the change in meat price did not affect them, as the change was affordable.

\subsection{Meat-consumption pattern: before and during the lockdown}

According to national health data analyzed by IndiaSpend, $80 \%$ of men and $70 \%$ of women are non-vegetarians (IndiaSpend, 2018). National Family Health Survey found that $42.8 \%$ of women and $48.9 \%$ of men consume a non-vegetarian diet (National Family Health Survey-4, 2017). Most non-vegetarian populations are found in the south and north-east parts of India (IndiaSpend, 2018).

In the present study, $30 \%$ of respondents were consuming meat twice a week, and $27 \%$ consumed it once a week. Altogether more than $80 \%$ of the respondents reported to consumed meat regularly, at least once a week. However, during the lockdown period, the meat consumption pattern was found to be changed. Among the participants, $26 \%$ responded that they are consuming meat once a month or less, whereas $21 \%$ consumed meat or meat products twice in a month. However, only $27 \%$ of respondents are consuming meat regularly, at least twice a week.

The quantity of meat purchased by the consumers during the lockdown period was reduced according to $60 \%$ of the meat-eating population. However, in the areas where the meat and meat products are readily available, the quantity of meat purchased was increased due to the higher consumption during the lockdown period. Among the respondents, $7 \%$ reported an increase in the quantity of meat procured than the previous months, whereas $33 \%$ responded that the quantity remained the same. The negative impact of the COVID-19 pandemic and lockdown on the family income might have contributed to the difficulty in the procurement of costly meat in certain families.

Indians are very fond of traditional meat products. One of the major sources of these products is the hotels and roadside vendors. During the lockdown period, these kinds of resources ceased to work. Kebabs, tikkas, tandoori chicken, momos, and many other delicacies became unavailable as the restaurants were closed during the initial lockdown period. Although the restrictions were lifted in the later phases of lockdown that permitted the opening of hotels and restaurants, people were reluctant to dine out (India Today, 2020). The restriction imposed on gatherings like marriages and parties also reduced the consumption of various meat dishes. Furthermore, the suspension of tourism activities around the country also affected meat consumption.

\subsection{COVID-19: Myths and rumors}

SARS-CoV-2 was believed to have emerged from the wet animal market of Wuhan, China (Malik et al., 2020). Following the emergence, several rumors were generated that linked consumption of meat and meat products with the origin of SARS-CoV-2. The spread of fake news pertaining to the occurrence of COVID-19 and meat consumption, especially in the case of poultry meat, has affected $22 \%$ of the survey participants. It contributed to the generation of panic among the customers and kept them away from consuming meat and meat products. They even ceased the purchase of meat and meat products due to the spread of such rumors (Rzymski et al., 2021). However, the practical actions took by the government of India, the Food Safety and Standards Authority of India (FSSAI), and local legislation helped to quell the rumors and myths, thereby resolving the issue to a great extent (Chandran, 2020). The spread of awareness among the consumers enabled them to know the facts associated with this topic. In light of this, $72 \%$ of people responded that the fake news did not affect their meat-consumption pattern.

The misleading advertisements like "Move Away From Meat" to prevent future pandemics by PETA India (People for the Ethical Treatment of Animals) in daily newspapers further contributed to the spread of unscientific rumors among the public (PETA, 2020). The false accusation over poultry resulted in a crash of $80 \%$ sales in the major poultry-producing states (Ghosal, 2020). Simultaneous outbreaks of avian influenza in two districts of Kerala (The Hindu, 2020), and African swine fever (ASF) in Assam and Arunachal Pradesh (The Pig Site, 2020), also affected the meat consumption pattern badly. 


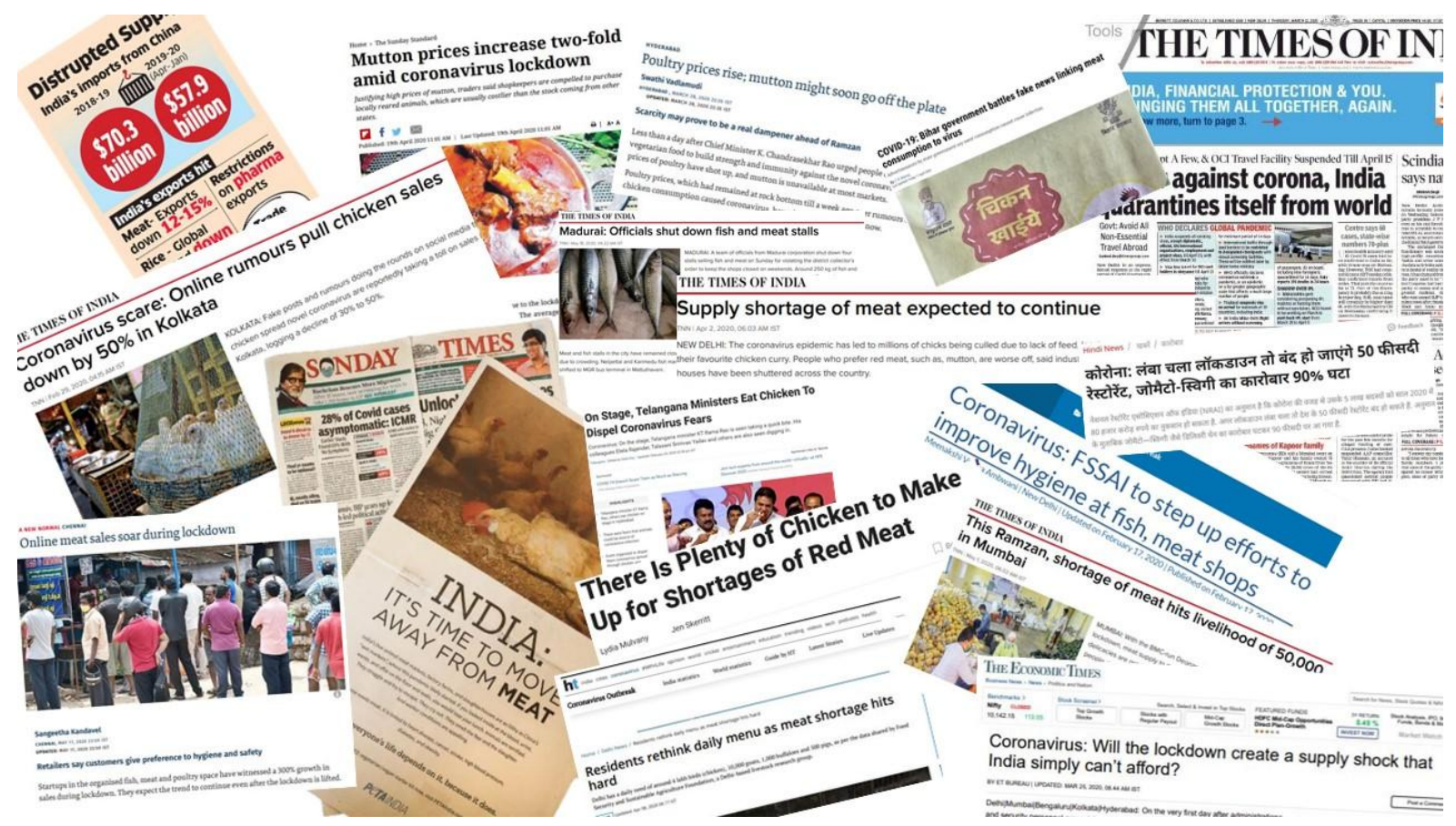

Figure 7 Collage of daily news related to COVID-19 and meat consumption

\subsection{Future of Indian meat consumerism}

Indian consumers are very fond of the non-vegetarian diet from ancient times onwards. In the older days, they used to cook at home and eat meat delicacies during special occasions. However, modern consumers changed their eating patterns, as they are more dependent on ready-to-eat delicacies, especially in urban areas. Hotels, restaurants, and online food delivery systems are favorites of modern meat consumers. The imposition of lockdown has affected the consumers and their eating patterns. A survey conducted by Dineout, a restaurant tech solutions platform, found that $77 \%$ of people want to dine out once the COVID-19 pandemic has subsided (Sharma, 2020).

The Indian meat industry possesses vast potential due to the diversity of consumers and the overall acceptability of meat and meat products throughout the country. The current situation can be tackled by enabling the transportation of livestock and its products with due precautions, following SOPs to conduct abattoir operations and processing in meat plants, selling meat and meat products in a well-maintained atmosphere with regulations, cooking and consuming according to scientific advisories. Indian Veterinary Research Institute has issued a public advisory to follow the procedures mentioned above during the COVID-19 pandemic. It can be adopted all over India (ICAR-IVRI, 2020).
The trend observed during the lockdown period indicates the vast opportunity of online meat marketing across the country. Successful implementation of strict quality control measures and an effective delivery system will ensure more consumer satisfaction. Mobile meat marketing can be adopted in meat scarce areas to increase the availability of meat and meat products in remote areas.

\section{Conclusion}

The countrywide lockdown and associated events affected the Indian meat industry badly. However, the meat consumers were mostly affected with the situation as they were forced to change their diet due to non-availability of certain commodities. About $70 \%$ of people reacted that the COVID-19 pandemic and the lockdown affected their consumption pattern. The sudden imposition of lockdown and the subsequent shutdown of the meat shops during the initial phase affected consumer. The relaxation made in the imposed restrictions and the implementation of specific facilities has enabled the delivery of meat and meat products to consumers for their daily use. However, in certain parts of the country, consumers were unsatisfied due to the unavailability of meat and meat products. More than half of the consumers were unsatisfied in terms of meat availability during the lockdown period. The dramatic changes in the meat and products 
industry affected the farmers, slaughterhouse workers, and mea consumers. The spread of rumors that linked meat consumption with the emergence of coronavirus infection pushed the price of meat to a minimum.

However, the price and demand for meat increased once the available stock became scarce. As a consequence of very high demand, the price of meat increased all over the country. On average, a $20-30 \%$ increase in the price was reported for meat all over the country and varied according to the type of meat and the region. Consequently, the consumers were forced to minimize the usage of meat and meat products that also contributed to the search for alternatives. The COVID-19 pandemic and the sudden imposition of lockdown affected almost all Indian meat consumers The slaughterhouses remained closed during the initial lockdown period, and the distribution of animal stocks wes also affected. The COVID-19 pandemic also affected the meat exports to other countries and thereby affecting the whole meat industry badly.

\section{Acknowledgements}

The authors are thankful to the participants who showed interest in this survey.

\section{Funding}

No substantial funding to be stated.

\section{Disclosure statement}

All authors declare that there exist no commercial or financial relationships that could, in any way, lead to a potential conflict of interest.

\section{References}

Anand J (2020) Unofficial restriction on selling meat hits retailers, The Hindu, Available at https://www.thehindu.com/news/cities/Delhi/unofficial-restrictionon-selling-meat-hits-retailers/article31350667.ece Accessed on March 5, 2021.

APEDA (2020) Agricultural and Processed Food Products Export Development Authority, Ministry of Commerce and Industry, Government of India, Available at http://agriexchange.apeda.gov.in/indexp/reportlist.aspx Accessed on: March 5, 2021.

Attwood S, Hajat C (2020) How will the COVID-19 pandemic shape the future of meat consumption?. Public Health Nutrition 23(17): 3116-3120.

Awasthi P (2020) Coronavirus: Lucknow bans open sale of all meat. The Week, Available at https://www.theweek.in/news/india/2020/03/05/coronaviruslucknow-bans-open-sale-of-all-meat.html Accessed on: March 5, 2021.

Bera S (2020) The great lockdown gums up animal farms, Live Mint, Available at https://www.livemint.com/news/India/the-greatlockdown-gums-up-animal-farms-11587570806854.html Accessed on: March 5, 2021.

Buch H (2020) Consumers preferred vegetarian food during lockdown: Nielsen India, Available at https://www.moneycontrol.com/news/business/companies/consum ers-preferred-vegetarian-food-during-lockdown-nielsen-India5303941.html Accessed on: March 5, 2021.

Chandran N (2020) Impact of COVID-19: Way Forward For Meat and Seafood Industry. Business World, Available at http://www.businessworld.in/article/Impact-Of-Covid-19-WayForward-For-Meat-And-Seafood-Industry/20-03-2020-186704/ Accessed on: March 5, 2021.

DADF Livestock Census (2019) Government of India, 20th Livestock Census-2019. Ministry of Fisheries, Animal Husbandry \& Dairying; Department of animal husbandry and dairying, Krishi Bhawan, New Delhi. Available at http://dadf.gov.in/sites/default/filess/Key\%20Results\%2BAnnexur e\%2018.10.2019.pdf Accessed on: March 5, 2021.

Dhama K, Patel SK, Yatoo MI, Tiwari R, Sharun K, Dhama J, Natesan S, Malik YS, Singh KP, Harapan H (2021) SARS-CoV-2 existence in sewage and wastewater: A global public health concern? Journal of Environmental Management 280: 111825.

FAS/USDA (2019) Foreign Agricultural Service United stated Department of Agriculture, Available at https://www.ers.usda.gov/amber-waves/2019/july/brazil-onceagain-becomes-the-world-s-largest-beef-exporter/ Accessed on March 5, 2021.

Faslu Rahman CK, Sharun K, Jose B, Dhama K (2020a) COVID19 and food safety: Implications and opportunities to improve the food supply chain. Journal of Experimental Biology and Agricultural Sciences 8(Spl-1- SARS-CoV-2):S34-S41.

Faslu Rahman CK, Sharun K, Tiwari R, Bilal M, Dhama K (2020b) Can unconventional meat or bushmeat act as a source for SARS-CoV-2? Journal of Experimental Biology and Agricultural Sciences 8(6):709-720.

Ghosal S (2020) Covid-19 lockdown has severely hit the poultry industry with Q4 being the worst quarter: ICRA. The Economic Times Available at https://economictimes.indiatimes.com/news/economy/agriculture/ 
covid-19-lockdown-has-severely-hit-the-poultry-industry-with-q4being-the-worst-

quartericra/articleshow/75351861.cms?utm_source=contentofinter est\&utm_medium=text\&utm_campaign=cppst Accessed on: March 5, 2021.

Graham F (2021) Daily briefing: Can COVID spread through frozen meat? Nature 2021.

Gupta V (2020) From airlifting meat to battling misinformation, how Licious, ZappFresh and FreshToHome kept pace with online deliveries during lockdown, ET online Available at https://economictimes.Indiatimes.com/small-

biz/startups/features/from-airlifting-meat-to-battling-

misinformation-how-licious-zappfresh-and-freshtohome-kept-

pace-with-online-deliveries-during-

lockdown/articleshow/75861342.cms?from $=\mathrm{mdr}$ Accessed on:

March 5, 2021.

Halabowski D, Rzymski P (2021) Taking a lesson from the COVID-19 pandemic: Preventing the future outbreaks of viral zoonoses through a multi-faceted approach. Science of the Total Environment 757: 143723.

ICAR-IVRI (2020) Advisory for Livestock Owners during COVID-19 Lockdown, ICAR-Indian Veterinary Research Institute, Izatnagar. Available at http://www.ivri.nic.in/circulars/advisory27042020.pdf Accessed on: March 5, 2021.

IndiaSpend (2018) Most Indians Non-Vegetarian; Men More Than Women, South \& East Most, IndiaSpend Available at https://www.Indiaspend.com/most-Indians-non-vegetarian-menmore-than-women-south-east-most-66469/ Accessed on: March 5, 2021.

India Today (2020) Unlock 4: Maharashtra allows hotels to operate at full capacity, lifts restrictions on inter-district movement Available at https://www.indiatoday.in/india/story/unlock-4maharashtra-allows-hotels-to-operate-on-full-capacity-liftsrestrictions-on-inter-district-movements-1717159-2020-08-31 Accessed on: March 5, 2021.

National Family Health Survey-4 (2017) International Institute for Population Sciences (IIPS) and ICF (2017) National Family Health Survey (NFHS-4), 2015-16: India. Mumbai: IIPS. Available at http://rchiips.org/nfhs/nfhs-4Reports/India.pdf Accessed on: March $5,2021$.

Lewis D (2021) Can COVID spread from frozen wildlife? Scientists probe pandemic origins. Nature 591(7848):18-19.
Malik YS, Sircar S, Bhat S, Sharun K, Dhama K, Dadar M, Tiwari R, Chaicumpa W (2020) Emerging novel coronavirus (2019$\mathrm{nCoV}$ )-current scenario, evolutionary perspective based on genome analysis and recent developments. Veterinary Quarterly 40(1): 68-76.

Mayasari NR, Ho DKN, Lundy DJ, Skalny AV, Tinkov AA, Teng IC, Wu MC, Faradina A, Mohammed AZM, Park JM, Ngu YJ, Aliné S, Shofia NM, Chang JS (2020) Impacts of the COVID-19 Pandemic on Food Security and Diet-Related Lifestyle Behaviors: An Analytical Study of Google Trends-Based Query Volumes. Nutrients 12(10): 3103.

Naveena BM, Kiran M (2014) Buffalo meat quality, composition, and processing characteristics: Contribution to the global economy and nutritional security. Animal frontiers 4(4): 18-24.

Pachchigar J (2020) Gujarat: Mutton shop owners held despite government nod to sell meat. The Times of India, Available at https://timesofIndia.Indiatimes.com/city/vadodara/mutton-shopowners-held-despite-govt-nod-to-sellmeat/articleshow/74954631.cms Accessed on: March 5, 2021.

PETA (2020) 'Time to Move Away From Meat' Full-Page Ad Blitz in D.C. to Hit the 'Examiner' Available at https://www.peta.org/media/news-releases/time-to-move-awayfrom-meat-full-page-ad-blitz-in-d-c-to-hit-the-examiner/ Accessed on: March 5, 2021.

Rzymski P, Kulus M, Jankowski M, Dompe C, Bryl R, Petitte JN, Kempisty B, Mozdziak P (2021) COVID-19 Pandemic Is a Call to Search for Alternative Protein Sources as Food and Feed: A Review of Possibilities. Nutrients 13(1): 150.

Sally M (2020) Lockdown blues: Meat: na mila re mannka, The Economic Times. Available at https://economictimes.Indiatimes.com/industry/consproducts/food/lockdown-blues-meat-na-mila-re-mannka/articleshow/75088164.cms?from=mdr Accessed on: March 5, 2021.

Sharma N (2020) 77 per cent people would prefer to dine out post COVID-19 pandemic: Survey, New Indian express. Available at https://www.newindianexpress.com/lifestyle/food/2020/may/08/77 -per-cent-people-would-prefer-to-dine-out-post-covid-19pandemic-survey-2140655.html Accessed on: March 5, 2021.

Sharun K (2020) SARS, MERS, and COVID-19: What's next? International Journal of Surgery 84: 66-68.

Sharun K, Tiwari R, Dhama K (2020) SARS-CoV-2 in semen: Potential for sexual transmission in COVID-19. International Journal of Surgery 84: 156-158. 
Sing G (2020) Non-vegetarian food does not cause COVID-19, \&utm_medium=text\&utm_campaign=cppst Accessed on March 5, says Minister, The Hindu, Available on 2021.

https://www.thehindu.com/news/national/non-vegetarian-fooddoes-not-cause-covid-19-says-minister/article31003791.ece Accessed on: March 5, 2021.

Special correspondent (2020) COVID-19 lockdown Meat stalls not allowed on narrow alleys, The Hindu. Available at https://www.thehindu.com/news/cities/Coimbatore/meat-stalls-notallowed-on-narrow-alleys/article31259589.ece Accessed on: March 5, 2021.

The Hindu (2020) Birds within 1-km radius of infected areas to be culled The Hindu, Available at https://www.thehindu.com/news/national/kerala/avian-influenzain-kozhikode/article31009733.ece Accessed on: March 5, 2021.

The Pig Site (2020) India reports African swine fever outbreaks in Assam and Arunachal Pradesh states, The Pig Site Available at https://thepigsite.com/news/2020/05/india-reports-african-swinefever-outbreaks-in-assam-and-arunachal-pradesh-states Accessed on March 5, 2021.

The Economic Times (2020) Coronavirus: Chicken prices fall, poultry industry affected, The Economic Times Tippana AN (2020) Kakinada bans sale of meat on Sundays. The Available at https://economictimes.Indiatimes.com/news/economy/indicators/co ronavirus-chicken-prices-fall-poultry-industry-

affected/articleshow/74546189.cms?utm_source=contentofinterest

Hindu, Available at https://www.thehindu.com/news/national/andhrapradesh/kakinada-bans-sale-of-meat-onsundays/article31292779.ece Accessed on: March 5, 2021. 